\title{
Public Need for an Arabic Language Teaching and Learning Module: Using al-Qur'an Approach
}

\author{
Suhaila Zailani \\ Universiti Kebangsaan Malaysia \\ Email: suzail@ukm.edu.my
}

Hakim Zainal

Universiti Kebangsaan Malaysia

Email: haza@ukm.edu.my

Salamiah Ab. Ghani

Universiti Kebangsaan Malaysia

Email: salma@ukm.edu.my

Khazri Osman

Universiti Kebangsaan Malaysia

Email:khazri@ukm.edu.my

Zainuddin Ismail

Universiti Kebangsaan Malaysia

Email: abuzaid@ukm.edu.my

Ummu Hani Hashim

Universiti Kebangsaan Malaysia

Email: ummuhani@ukm.edu.my

Doi:10.5901/mjss.2014.v5n29p54

\section{Abstract}

This purpose of this article is to identify Arabic language teaching and learning modules in the market which use the Quranic verses approach, and to obtain the views or perception of the general public towards learning Arabic language through alQur'an. This study used the questionnaire method. Findings showed that Arabic language modules available in the market have yet to fulfill the purpose for the public to learn the language. The findings of this study are useful to assist researchers in constructing an Arabic language teaching and learning module through al-Qur'an which meets the aspirations and wishes of the public in Malaysia, and to assist efforts which can increase the public interest to learn the language.

Keywords: module; teaching and learning; Arabic language; al-Qur'an; the public;

\section{Introduction}

Al-Qur'an is the mother of all knowledge and has spawned extensive offshoots of knowledge. As al-Qur'an was revealed in Arabic language, there is no other option to master the knowledge contained in it except by learning the Arabic language. Thus, the importance of Arabic language cannot be denied, particularly in the religious context. The general public in Malaysia therefore ought to learn the language to increase their understanding of the Islamic religion. The status of Arabic language as the language of al-Qur'an and its perpetuity and security are guaranteed by Allah S.W.T. A deep knowledge of Arabic is therefore the first prerequisite for mujtahidoon or jurists to qualify them to infer and deduce from religious sources and evidence through the process of ijtihad in matters of shariah. This is because a clear and accurate 
understanding of a certain law may be explained through an in-depth study of the Arabic language. However, for the general public who would like to understand and appreciate al-Qur'an, a basic knowledge of Arabic is sufficient.

Basic knowledge of Arabic language such as knowledge of the type of words, function of articles, personal pronouns, gender, numerals and differences of meanings due to differences in form or pattern of a words, is sufficient to assist readers in being more careful or discriminating when reading al-Qur'an beside assisting them to understand simple sentences, particularly short surahs in al-Qur'an. Lately, the obligation to learn Arabic language is beginning to be realized by the general public. This is probably due to many religious programs such as lectures, talks and forums aired on electronic media which call on, exhort and encourage the society to study religious precepts, particularly to learn Arabic language as the main medium to understand al-Qur'an.

\section{Research Objectives}

The research objectives were:

- To study the Arabic language teaching and learning modules found in the market.

- To identify the factors of motivation for, interest in and perception of the general public towards learning Arabic language.

\section{Research Methodology}

This research combined two research methods, namely qualitative and quantitative. The qualitative method was used to gather information from books and modules of teaching Arabic related to teaching Arabic through al-Qur'an. The qualitative method used questionnaires.

\subsection{Research Respondents}

Research respondents comprised of members of the general public in Malaysia. The number of respondents was targeted at 200 people randomly selected to give feedback on the research instrument. However, only 162 people have given their feedback in response. Below is the frequency of respondents according to State.

Table 1. Frequency of Respondents According to State

\begin{tabular}{lc}
\hline State & Total \\
\hline Negeri Sembilan & 30 \\
Kuala Lumpur & 25 \\
Sarawak & 19 \\
Kelantan & 19 \\
Sabah & 10 \\
Terengganu & 10 \\
Selangor & 11 \\
Kedah, Penang Island & 11 \\
Malacca & 7 \\
Pahang & 7 \\
Johore & 6 \\
Federal Territory (Putrajaya and Labuan) & 7 \\
\hline Total & 162 \\
\hline
\end{tabular}

Table 2. Information on Respondents (Gender)

\begin{tabular}{lccc}
\hline & & Frequency & Percentage \\
\hline \multirow{3}{*}{ Valid } & Male & 65 & 40.1 \\
& Female & 95 & 58.6 \\
& Total & 160 & 98.8 \\
Missing & System & 2 & 1.2 \\
\hline Total & & 162 & 100.0 \\
\hline
\end{tabular}


Table 2 shows information on respondents according to gender. The majority of respondents who participated in this study were women, 95 persons or $58.6 \%$ compared to men, 65 persons or $40.1 \%$.

Table 3. Information on Respondents (Occupation)

\begin{tabular}{llcc}
\hline & & Frequency & Percentage \\
\hline Valid & Civil servants & 72 & 44.4 \\
& Private sector Employees & 31 & 19.1 \\
& Housewives & 23 & 14.2 \\
& Retirees/Pensioners & 22 & 13.6 \\
& Others & 10 & 6.2 \\
& Total & 158 & 97.5 \\
Missing & System & 4 & 2.5 \\
\hline \multicolumn{2}{r}{ Total } & 162 & 100.0 \\
\hline
\end{tabular}

Table 3 shows that $44.4 \%$ of respondents were civil servants, $19.1 \%$ were from the private sector, $14.2 \%$ were housewives and $13.6 \%$ were retirees or pensioners. Research findings indicate that civil servants dominated this study, followed by private sector employees, with a significant difference of $25.3 \%$.

Table 4. Information on Respondents (Basic Education)

\begin{tabular}{llcc}
\hline & & Frequency & Percentage \\
\hline Valid & Religious Stream & 58 & 35.8 \\
& Non-religious Stream & 75 & 46.3 \\
& Others & 21 & 13.0 \\
& Total & 155 & 95.7 \\
\multirow{2}{*}{ Missing } & System & 7 & 4.3 \\
\hline \multicolumn{2}{r}{ Total } & 162 & 100.0 \\
\hline
\end{tabular}

In Table 4, the researcher finds that people from the non-religious stream were more interested to learn Arabic language compared to those from the religious stream. $46.3 \%$ representing 75 respondents stated their interest in learning Arabic language compared to only $35.8 \%$ or 58 respondents from the religious stream. This was probably due to the latter having already studied Arabic since primary schools.

Table 5. Respondents' Level of Education

\begin{tabular}{llcc}
\hline & & Frequency & Percentage \\
\hline Valid & SPM (Secondary School) & 51 & 31.5 \\
& STPM (High School) & 24 & 14.8 \\
& Bachelor Degree & 52 & 32.1 \\
& Master Degree & 11 & 6.8 \\
& Ph.D. & 2 & 1.2 \\
& Total & 140 & 86.4 \\
& System & 22 & 13.6 \\
\hline \multicolumn{2}{c}{ Total } & 162 & 100.0 \\
\hline
\end{tabular}

Of 162 research respondents, 52 of them or $32.1 \%$ who were interested in or were learning Arabic language were graduates with a Bachelor Degree. Almost the same number, 51 persons or $31.5 \%$ represented the public with SPM (Secondary School) qualification. However, those who had a Ph.D. were also interested in learning Arabic language although they constituted only a tiny minority of $1.2 \%$ or 2 respondents. Research findings show that the majority of the public who were interested in or were already learning Arabic language had an educational level of at least SPM (Secondary School Education). 
Table 6. Ability to Read al-Qur'an

\begin{tabular}{llcc}
\hline & & Frequency & Percentage \\
\hline \multirow{3}{*}{ Valid } & Good ( Fluent) & 112 & 69.1 \\
& Average (Not Fluent) & 49 & 30.2 \\
& Weak (Unable to Read) & 1 & 0.6 \\
\hline Total & & 162 & 100.0 \\
\hline
\end{tabular}

The table above gives an actual picture of the respondents' ability to read al-Qur'an. Of 162 respondents, 112 persons or $69.1 \%$ were able to read al-Qur'an well and fluently. 49 respondents or $30.2 \%$ were at average level, able to read alQur'an but not fluently. Only one respondent was weak or did not know how to read al-Qur'an. This clearly shows that most of the people who participated in this research had a good or average ability to read al-Qur'an. Those in society who are able to read al-Qur'an well and fluently are the target group of the researcher because those who do not know how to read and are not fluent would do better to learn to read al-Qur'an before learning Arabic language.

Table 7. Ability to Write Jawi (Arabic Script)

\begin{tabular}{llcc}
\hline & & Frequency & Percentage \\
\hline Valid & Yes, Highly Skilled & 85 & 52.5 \\
& Yes, Less Skilled & 68 & 42.0 \\
& Not Skilled & 6 & 3.7 \\
& Total & 159 & 98.1 \\
\multirow{2}{*}{ Missing } & System & 3 & 1.9 \\
\hline Total & & 162 & 100.0 \\
\hline
\end{tabular}

As is generally known, Jawi writing or script is very closely related to the Arabic language because it uses the Arabic alphabets. The term Jawi writing/script is known only in Malaysia, Singapore, South Thailand Selatan and Brunei Darussalam, whereas in Indonesia, this writing is known as "Arabic-Malay writing". For this reason, it is not peculiar to say that people who are skilled in Jawi writing are more interested to learn Arabic compared to those who do not. This is because proficiency in Jawi writing is tremendously helpful in learning Arabic. This can be seen in the Table above. Of 162 respondents, 85 of them or $52.5 \%$ were very skilled in Jawi writing, followed by the less skilled group of 68 persons or $42.0 \%$.

\subsection{Factors for Learning Arabic Language by the General Public}

In this part, the researcher lists down 8 factors which influenced respondents to learn Arabic language.

Table 8. Factors for Learning Arabic Language

\begin{tabular}{lcc}
\hline Item & Frequency & Percentage \\
\hline To understand al-Qur'an & 103 & 63.6 \\
To understand recitations in prayers & 97 & 59.9 \\
Self-awareness & 93 & 57.4 \\
Desire to communicate & 89 & 54.9 \\
Requirement in course of study & 74 & 45.7 \\
Influenced by mass media advertisement & 62 & 38.3 \\
Work requirement & 61 & 37.7 \\
Friend's solicitation & 52 & 32.1 \\
\hline
\end{tabular}

These factors were selected based on the normal interest of the society to learn Arabic. Research findings show the first factor, learning Arabic to understand al-Qur'an had the most frequency, 103 respondents or $63.6 \%$. Next, in second and third places were the factors to understand recitations in prayers and self-awareness, representing $59.9 \%$ and $57.4 \%$ of research respondents respectively. These findings show that majority of respondents agreed that they learnt Arabic for the purpose of understanding al-Qur'an and recitations in prayers. Their agreement on these two factors was most probably caused by the third factor, the self-awareness of respondents on the importance of learning this language. The respondents' desire to communicate in Arabic was the fourth factor followed by the factor of course requirement in their 
field of study. The factor of friend's solicitation was not less important after the factors of influence of mass media advertisement and work requirement. All the factors listed in the Table below were seen as important factors which contributed to the increase in interest and awareness of the public to learn Arabic.

\subsection{Reasons for Not learning Arabic Language}

Table 9 below lists down the 6 reasons for the general public not learning Arabic language.

Table 9. Reasons for the General Public Not Learning Arabic Language

\begin{tabular}{|l|c|c|}
\hline Item & Frequency & Percentage \\
\hline No opportunity to learn it & 18 & 11.1 \\
\hline No time to learn it & 8 & 4.9 \\
\hline Not aware it is important & 5 & 3.1 \\
\hline No necessity to learn it & 3 & 1.9 \\
\hline It is less important than other languages & 2 & 1.2 \\
\hline No interest to learn it & 1 & 0.6 \\
\hline
\end{tabular}

Underlying the open opportunity for the public to understand al-Quran and learn Arabic, there are a few who claimed that one of the reasons for not learning Arabic language was the lack of opportunity to learn it. The group with this presumption numbered 18 people out of 162 respondents or $11.1 \%$. Eight respondents or $4.9 \%$ gave the excuse that they did not have the time to learn it, five respondents or $3.1 \%$ say that they did not know that learning Arabic is important. The rest said they had no necessity to learn it (3 respondents or 1.9\%), followed by those who said that Arabic language is less important than other languages (2 respondents or $1.2 \%$ ) and lastly, one person (0.6\%) said that he was not interested.

\subsection{Public Perception Towards Learning Arabic Language}

In this part, the researcher displays three scales: combination of scales 5 and 4 (SA \& A), scale 3 (NS) and combination of scales 2 and 1 (D \& SD) for the frequency and percentage of respondents who agree, are unsure and disagree over the 8 items as follows:

Table 10. Perception of public towards learning Arabic language

\begin{tabular}{|c|c|c|c|}
\hline Item & $\begin{array}{l}\text { Strongly Agree \& Agree } \\
\text { (SA \& A) }\end{array}$ & $\begin{array}{l}\text { Not Sure } \\
\text { (NS) }\end{array}$ & $\begin{array}{l}\text { Disagree \& Strongly } \\
\text { Disagree (DS \& D) }\end{array}$ \\
\hline Arabic language is an important language. & $116(71.6 \%)$ & $21.2 \%)$ & $40(24.7 \%)$ \\
\hline Arabic language proficiency is currently important. & $84(51.9 \%)$ & $16(9.9 \%)$ & $56(34.6 \%)$ \\
\hline Muslims are obliged to learn Arabic language. & $100(61.7 \%)$ & $12(7.4 \%)$ & $45(27.8 \%)$ \\
\hline $\begin{array}{l}\text { I do not feel any loss from not understanding recitations } \\
\text { during prayers. }\end{array}$ & $43(26.5 \%)$ & $5(3.1 \%)$ & $106(65.4 \%)$ \\
\hline I am happy to learn Arabic language through al-Qur'an. & $113(72.2 \%)$ & $4(2.5 \%)$ & $37(22.8 \%)$ \\
\hline $\begin{array}{l}\text { I understand al-Qur'an verses based on Arabic language } \\
\text { proficiency. }\end{array}$ & $69(42.5 \%)$ & $22(13.6 \%)$ & $67(41.3 \%)$ \\
\hline $\begin{array}{l}\text { Examples of al-Qur'an verses are very helpful in improving } \\
\text { mastery of Arabic language. }\end{array}$ & $73(45.1 \%)$ & $12(7.4 \%)$ & $74(45.7 \%)$ \\
\hline $\begin{array}{l}\text { Arabic books available in the market are more inclined } \\
\text { towards understanding al-Qur'an. }\end{array}$ & $36(22.2 \%)$ & $80(49.4 \%)$ & $38(23.4 \%)$ \\
\hline
\end{tabular}

Table 10 above shows that of 162 respondents, 116 persons or $71.6 \%$ strongly agreed that Arabic is an important language. However, 40 persons or $24.7 \%$ disagreed with this statement. 84 respondents or $51.9 \%$ strongly agreed that proficiency in Arabic language is currently important, whereas 34.6\% disagreed with this. 98 respondents or $60.5 \%$ strongly agreed with the statement that it is obligatory for Muslims to learn Arabic language. 94 respondents or $58 \%$ felt the loss in not understanding recitations during prayers, and 113 respondents or $72.2 \%$ felt happy to learn Arabic through al-Qur'an verses. 
For the sixth item, the combined percentage for Strongly Agree and Agree (SA \& A) that they were able to understand Quranic verses based on Arabic language proficiency (69 respondents or 42.5\%) is almost equal to the combined percentage of those who Strongly Disagree and Disagree ( SD \& D) (67 respondents or 41.3\%) with the said item. Likewise with the seventh item, there is no significant difference between the percentage of those who chose scales Strongly Agree and Agree (SA \& A), with the percentage of those who chose the scales Strongly Disagree and Disagree (SD \& D). The last item shows that the percentage of respondents who chose the scale Not Sure (NS) exceeds the percentage of other scales by $49.4 \%$ representing 80 respondents. Only 36 respondents or $22.2 \%$ Strongly Agree and Agree (SA \& A) with the statement that Arabic books available in the market are more inclined to understanding Al-Quran. This situation is not very different from the percentage of respondents who Strongly Disagree and Disagree with the said statement.

\subsection{Approach of Arabic Language Teaching Module}

Scales 5 and 4 (SA \& A) were combined to obtain the frequency and percentage in order to determine the following matters:

- Suitability level of the Arabic teaching module approach to meet the desired requirement of the general public.

Table 11. Approach of Arabic Language Module

\begin{tabular}{lcc}
\hline Item & Frequency (162) & Percentage (100) \\
\hline Al-Quran Approach & 135 & 83.3 \\
Nahu (Grammar) Approach (Sentence Formation) & 133 & 82.1 \\
Through recitations in Prayers & 132 & 81.5 \\
Communication Approach & 131 & 80.8 \\
Sarf (Morphology) Approach (Word Formation) & 129 & 79.6 \\
Through daily Doa (Supplication) & 126 & 77.8 \\
\hline
\end{tabular}

From the table above, the researcher finds that the Arabic language teaching and learning module favored by the public was the module which combined all the above six approaches. However, the al-Qur'an approach prevailed over the others.

- Steps taken by the general public to understand al-Qur'an.

Table 12. Steps Taken by the Public to Understand al-Qur'an

\begin{tabular}{lcc}
\hline Item & Frequency (162) & Percentage (100) \\
\hline Read interpretation/commentary of al-Qur'an itself & 115 & 71.0 \\
Ask the Ustaz/Ustazah questions & 96 & 59.3 \\
Learn Arabic language & 96 & 59.2 \\
Study interpretation of al-Qur'an & 93 & 57.4 \\
Reference to Al-Quran per word & 91 & 56.2 \\
\hline
\end{tabular}

The table above explains the efforts taken by the public to understand al-Qur'an. In this study, it was found that a relatively high percentage of the public took the reading of al-Qur'an interpretation or commentary as a measure to understand the al-Qur'an. Even though reading the interpretation itself is a commendable effort, without a basic knowledge of Arabic, one would not be able to understand the secrets contained in the use of the Arabic language itself. Only $59.2 \%$ of respondents made the effort to learn Arabic language to understand al-Qur'an compared to $71.0 \%$ of respondents who were more inclined to read the interpretation of the al-Qur'an.

Table 13. The Necessity of Learning Arabic Language to Understand al-Qur'an

\begin{tabular}{ccc}
\hline Item & Frequency & Percentage \\
\hline View as Necessary & 153 & 94.4 \\
View as Unnecessary & 2 & 1.2 \\
\hline Total & 162 & 100
\end{tabular}


The table above shows the views of the public towards the necessity of learning Arabic to understand al-Qur'an. From the table above, 153 respondents or $94.4 \%$ stated that it was necessary to learn Arabic language to understand al-Qur'an. Only 2 respondents or $1.2 \%$ said that it was unnecessary to learn it to understand al-Qur'an.

\section{Conclusion}

This study found that the main objective of the public in learning Arabic language was to understand al-Qur'an and recitations in prayers. In addition, they had the awareness that learning Arabic language is very important to understanding al-Qur'an and recitations in prayers. Research findings also showed that most people in Malaysia have a deep interest in learning Arabic language. However, a small minority of them, (24.7\%) disputed the fact that Arabic is an important language. The reasons they gave for not learning Arabic were that they do not know that it is an important language and that they assumed that it was less important than other languages. However, the percentage of those with this excuse was small while the percentage of those who Strongly Agree and Agree (scales SA \& A) for items 1, 2 and 3 in Table 12 shows a high level of awareness on the importance of Arabic and the obligation to learn it on the part of the public. The necessity to learn Arabic for the purpose of understanding al-Qur'an and recitations in prayers are equally important to the need to produce a book or construct a module for teaching and learning Arabic which fulfills the said purpose.

\section{Acknowledgement}

This study is financed by the Research Group of Arabic Culture and Islamic Civilization (KUKAPI, DPP-2014-068), UKM; the Action/Strategic Research Project (PTS-2012-061; PTS-2014-068), UKM; the University-Community Incentive Grant (KOMUNITI-2011-016), UKM; and the Arus Perdana Project (AP-2012-001; AP-2013-017; AP-2014-006), UKM.

\section{References}

A. Rahman, H. Salimudin. (2007). Tatabahasa Arab untuk Mempelajari al-Qur'an (Arabic Grammar for Studying al-Qur'an). Bandung: Sinar Baru Algensindo.

Abd Rahman, Lubnan, A. Bakar, Aznida, Wan Ahmad, Wan Azura. (2008). Mengenali Bahasa Arab Menerusi al-Qur'an (Knowing Arabic through al-Quran). Nilai: Penerbit USIM.

Abdel Moneim Sery, Sohair. (2010). Pengajaran Bahasa Arab Menerusi al-Qur'an (Teaching of Arabic Language through al-Qur'an). Pustaka Haji Abdul Majid.

al-Aisary, Abu Hamzah Yusuf. (2007). Pengantar Mudah Belajar Bahasa Arab (Introduction to Easy Learning of Arabic Language). Bandung: Pustaka Adhwa.

Anwar, Rosihon M. Ag. (2002). Cara Praktis Belajar dan Memahami Bahasa al-Qur'an (Practical Method of Learning and Understanding the Language of al-Qur'an). PT. ALMA 'ARIF.

Che Mat, Azman, Hashim, Md Radhi \& Yaakub, Ahmad Faiz. (2005). Kecenderungan pelajar memilih bahasa Arab sebagai bahasa asing di UiTM dan KUSZA: Satu perbandingan (Inclination of Students in Opting for Arabic language as a foreign language in UiTM and KUSZA: A Comparison). Projek kajian dengan geran IRDC (Institute of Research, Development and Commercialization), Universiti Teknologi MARA, Shah Alam, Malaysia.

Hakim. (2012). Rumusan kajian persepsi orang awam terhadap pembelajaran bahasa Arab menerusi al-Qur'an di Malaysia (Research Conclusions on the Perception of the Public towards Learning Arabic Language through al-Qur'an in Malaysia). Retrieved from http://www.ukm.my/uba/sebar2012/Prosiding\%20 SEBAR2012/27.Ummu Hani.pdf

Hamid, A.W. (1998). Access to Quranic Arabic. London NW4 2RX, UK: MELS.

Hashim, Ummu Hani, Zailani @ Ahmad, Suhaila, Ab. Ghani, Salamiah, Osman, Khazri, Ismail, Zainuddin \& Zainal,

Ismail, Mohd Rosdi \& Pa, Mat Taib. (2006). Pengajaran dan Pembelajaran Bahasa Arab di Malaysia (Teaching and Learning of the Arabic language in Malaysia). Kuala Lumpur: Universiti Malaya.

Ismail, Zainuddin, Yaacob, Ibrahim \& Ab. Ghani, Salamiah. (2010). Asas Bahasa Arab melalui al-Qur'an (Basics of Arabic Language through al-Qur'an). Bangi: Unit Bahasa Arab, Fakulti Pengajian Islam, Universiti Kebangsaan Malaysia.

Mohamed, Ahmad Kilani. (2001). Teori Pengajaran dan Pembelajaran Bahasa Arab di Sekolah Menengah Agama di Malaysia (Theory of Teaching and Learning Arabic Language in Religious Secondary Schools in Malaysia). Skudai: Penerbit Universiti Teknologi Malaysia.

Muhammad, Azhar. (2005). Beberapa aspek keunikan dan keistimewaan bahasa Arab sebagai bahasa al-Qur'an (Some Aspects in the Uniqueness and Distinctiveness of Arabic Language as the Quranic Language). Jurnal Teknologi, 42(E), 61-76.

Piaw, Chua Yan. (2006). Kaedah Penyelidikan (Research Methodology). Kuala Lumpur: McGraw Hill (Malaysia) Sdn. Bhd.

Raja Mohd Dain, Raja Mukhtaruddin. (1979/1980). Kaedah dan Teknik Mengajar Bahasa (Methods and Techniques in Teaching Language). Kuala Lumpur: Pustaka IImu. 
Samah, Rosni. (2007). Penggunaan internet dalam pengajaran bahasa: Kajian terhadap bahasa Arab komunikasi pelancongan (Use of the Internet in Teaching of language: Study of Communication in Arabic for Tourism). Retrieved from http://web.usm. my/education/MEDC/Vol1/920PENGGUNAAN\%20INTERNET\%20DALAM\%20PENGAJARAN\%20 BAHASA.pdf

Sini, Mahmud Ismacil, cAbd al-cAziz, Nasif Mustafa \& Husayn, Mukhtar al-Tahir. (1983). Al-'Arabiyyah lil-Nashi'in (Arabic for Beginners). Arab Saudi: al-Mamlakah al-'Arabiyyah al-Sa'udiyah Wizarat al-Ma'arif.

Wan Ahmad, Wan Azura, Abd Rahman \& Lubna, A. Bakar, Aznida. (2007). Pendekatan dan Strategi Efektif Dalam Penguasaan Bahasa Arab (Effective Approach and Strategy in the Mastery of Arabic Language). Nilai: Penerbit Universiti Sains Islam Malaysia.

Yusuf, Mohd Fauzi \& Seman, Muhammad. (2010). al-cArabiyah lil-cibadah (Arabic for Worship). Kuala Lumpur: Institut Terjemahan Negara Malaysia.

Zailani @ Ahmad, Suhaila, Ab. Ghani, Salamiah, Hashim,Ummu Hani, Osman, Khazri, Ismail, Zainuddin \& Zainal, Hakim. (2012). Modul pengajaran dan pembelajaran bahasa Arab menerusi al-Qur'an (Arabic Language Teaching and Learning Module through alQur'an). Retrieved from http://www.ukm.my/uba/sebar2012/Prosiding\%20 SEBAR2012/19.Suhaila.pdf

Zubir, Badri Najib. (2009). Kaedah-kaedah Tasrif Bahasa Arab (Rules of Morphology in Arabic Language). Gombak: International Islamic University of Malaysia Press. 